\title{
Correction to: Extraforal nectary-bearing plant Mallotus japonicus uses diferent types of extraforal nectaries to establish efective defense by ants
}

\author{
Akira Yamawo $^{1} \cdot$ Nobuhiko Suzuki $^{1} \cdot$ Jun Tagawa ${ }^{2}$
}

Published online: 25 April 2020

(c) The Author(s) 2020

\section{Correction to: Journal of Plant Research (2019) 132:499-507 https://doi.org/10.1007/s10265-019-01119-5}

The article Extraforal nectary-bearing plant Mallotus japonicus uses diferent types of extraforal nectaries to establish efective defense by ants, written by Akira Yamawo, Nobuhiko Suzuki and Jun Tagawa, was originally published Online First without Open Access. After publication in volume 132, issue 4, page 499-507 the author decided to opt for Open Choice and to make the article an Open Access publication. Therefore, the copyright of the article has been changed to (C) The Author(s) 2020 and the article is forthwith distributed under the terms of the Creative Commons Attribution 4.0 International License (https://creativecommons .org/licenses/by/4.0/), which permits use, duplication, adaptation, distribution and reproduction in any medium or format, as long as you give appropriate credit to the original author(s) and the source, provide a link to the Creative Commons license, and indicate if changes were made.

The original article was updated.

The original article can be found online at https://doi.org/10.1007/ s10265-019-01119-5.

Akira Yamawo

yamawo.aki@gmail.com

1 Department of Applied Biological Sciences, Facultyof

Agriculture, Saga University, Saga 840-8502, Japan

2 Department of Biosphere-Geosphere System Science,Faculty of Informatics, Okayama University of Science, Okayama 700-0005, Japan
Open Access This article is licensed under a Creative Commons Attribution 4.0 International License, which permits use, sharing, adaptation, distribution and reproduction in any medium or format, as long as you give appropriate credit to the original author(s) and the source, provide a link to the Creative Commons licence, and indicate if changes were made. The images or other third party material in this article are included in the article's Creative Commons licence, unless indicated otherwise in a credit line to the material. If material is not included in the article's Creative Commons licence and your intended use is not permitted by statutory regulation or exceeds the permitted use, you will need to obtain permission directly from the copyright holder. To view a copy of this licence, visit http://creativecommons.org/licenses/by/4.0/.

Publisher's Note Springer Nature remains neutral with regard to jurisdictional claims in published maps and institutional affiliations. 